\title{
Withdrawal from telescope project ruins space plans
}

\section{Sydney}

Two years after the Australian Space Board was set up, Australia's National Space Program is still not off the ground. In its first two years its budget has been restricted to funding previous commitments and has dropped from $\mathrm{A} \$ 5.25$ million in $1986-87$ to $\mathrm{A} \$ 3.2$ million in 1987-88. Now comes news that one of its key projects, the Lyman ultraviolet satellite-borne telescope, is to be abandoned.

The Lyman telescope was to be a joint project between Europe, the United States and Australia. Australia was invited to take part because of the preeminence of astronomers at the Mount Stromlo and Siding Spring Observatories in developing ultraviolet detector assays. The European Space Agency (ESA) is to decide next month whether to proceed with Lyman.

The end of Australian participation in the Lyman project is a consequence of the government's reorganization of science over the past two years. When Australia first became involved in the Lyman project, there was an independent Department of Science, with an independent

\section{Soviet archaeological sites threatened by developers}

\section{London}

THE discovery of Moscow's first birchbark manuscript last month has again called into question the efficacy of Soviet laws on the protection of archaeological sites. Theoretically, the rules are clear; no civil engineering work in areas thought to contain archaeological remains, except by agreement with officials responsible for the protection of ancient monuments. But only last-minute intervention has rescued what seems to be an important new site.

Under the rules, even if remains come to light in what was previously thought to be virgin ground, all construction work must cease until the site has been properly excavated and recorded. But the Moscow birch-bark manuscript was uncovered in one of the most historic parts of Moscow, near the Resurrection Gate, during improperly sanctioned road repairs.

A team from the Institute of Archaeology of the Academy of Sciences of the USSR and the Moscow City Party Committee heard of the discovery and launched a rescue dig of what proved to be settlement layers dating back to the thirteenth century. The birch-bark manuscript, discoverd in the fifteenth-century level, is a $16 \times 3 \mathrm{~cm}$ fragment containing 17 lines with four or five letters in each line, written across the grain of the bark, and appears to be part of a letter.

The Soviet Union is relatively poor in historical manuscripts (the recent Catalogue of Slavonic-Russian manuscript books conserved in the USSR lists about 500 from the eleventh to thirteenth centuries). The traditional use of wood as the principal building material in Russia, and the consequent frequent and disastrous fires, meant that relatively few manuscripts survived. During the past three decades, however, some 250 birch-bark manuscripts have been found at various sites in Russia and also Zvenigorod in western Ukraine. But it is estimated that as many as 20,000 more remain to be discovered in the Novgorod area alone - if the developers do not get to them first.

Moscow City Council is at present preparing new rules on the city's archaeology, which Pravda urges should not be delayed. The matter is especially urgent because reconstruction of the historic city centre is due to begin next year.

Whatever rules emerge, experience has shown that their usefulness will depend on a sufficiency of trained archaeologists to supervise excavations. But such specialists are in short supply.

The humanities, including archaeology, are low on the priority lists of the Academy of Sciences, the higher education system and the Soviet government planners. Moscow and Leningrad Universities each turn out around ten trained archaeologists a year, which would barely compensate for natural wastage, even if they all went straight into jobs in say, city planning, where archaeologists are urgently needed. In practice, the Soviet system by which new graduates repay the state for their education by serving in an assigned job for three years, means that many of these young archaeologists are sent to secondary schools, where their expertise is wasted. There is virutally no effective archaeological service, even in historic cities such a Pskov and Novgorod, to be developed as tourist centres.

The "Moscow archaeological expedition" of the Academy of Sciences, its director, Dr V Alekseev commented in Pravda, "includes fewer specialists than the fingers on one hand". And while Moscow has no special archaeological service, Prague, for example, has an efficient one staffed by 40 fully trained archaeologists. minister, Barry Jones, at its head. Subsequently, the Department of Science was dismembered and its functions scattered. Many of them were absorbed by the Department of Industry, Technology and Commerce (DITAC), where Jones now serves as a junior minister.

The Space Board operates under the auspices of DITAC and its chief mission is now to encourage the development of space industry. It takes the view that expensive science projects such as the Lyman telescope are not the most costeffective way to use Australian industrial capabilities, and that such space science would more properly be funded by a scientific grants body such as the Australian Research Council.

This year (1988-89), the Space Board's budget has been restored to $\mathrm{A} \$ 5.4 \mathrm{mil}$ lion, but most is earmarked for an Australian ground station to receive data from ERS-1, the European remote sensing satellite scheduled for launch early in 1990 (see page 581).

The Space Board will spend a large portion of the remainder of its budget on consultants who will prepare an Australian Space Industry Development Strategy. But some feel this money will be wasted. Ted Stapinski, general manager of Auspace which had the main contracts for the Lyman telescope project, points out that the earlier Madigan report mapped out what Australia should do in space. He describes Australia's space policy as "running around in circles without getting anywhere".

The Madigan report recommended that a space board be set up as a statutory body and that $\mathrm{A} \$ 500$ million be spent over a period of five years. A national space programme would serve the country's needs in communications, resource management, remote sensing, surveillance and science.

Australia spends far less on space per head of population that comparable countries. In addition to the budget of the Australian Space Board, Australia will spend a further A $\$ 5.2$ million on space through its largest research body the Commonwealth Scientific and Industrial Research Organization (CSIRO). Taken together with university-based research, this gives an expenditure of about $\mathrm{A} \$ 0.70$ per person annually. In Canada the figure is $\mathrm{A} \$ 5.70$, Sweden spends $\mathrm{A} \$ 4.70$, and in the United States the National Aeronautics and Space Administration alone spends A $\$ 41$ per head of population annually.

According to Stan Schaetzel, who is technical director of Australia's largest aerospace company, Hawker De Havilland Ltd, and the man who conceived the Cape York Spaceport proposal, these statistics reflect the fact that the Australian government has completely failed to see the potential of space industry.

Charles Morgan 